University of Nebraska - Lincoln

DigitalCommons@University of Nebraska - Lincoln

September 1990

\title{
Radiosensitivity Parameters for Cell Survival in Tradescantia and for Chromosome Aberrations in Chinese Hamster Cells
}

Robert Katz

University of Nebraska-Lincoln, rkatz2@unl.edu

G. Huang

University of Nebraska-Lincoln

Follow this and additional works at: https://digitalcommons.unl.edu/physicskatz

Part of the Physics Commons

Katz, Robert and Huang, G., "Radiosensitivity Parameters for Cell Survival in Tradescantia and for Chromosome Aberrations in Chinese Hamster Cells" (1990). Robert Katz Publications. 134.

https://digitalcommons.unl.edu/physicskatz/134

This Article is brought to you for free and open access by the Research Papers in Physics and Astronomy at DigitalCommons@University of Nebraska - Lincoln. It has been accepted for inclusion in Robert Katz Publications by an authorized administrator of DigitalCommons@University of Nebraska - Lincoln. 
Published in Radiation Protection Dosimetry 31:1-4 (1990), pp. 261-263. Copyright ( 1990 Nuclear Technology Publishing/Oxford University Press. Used by permission. http://rpd.oxfordjournals.org/

\title{
Radiosensitivity Parameters for Cell Survival in Tradescantia and for Chromosome Aberrations in Chinese Hamster Cells
}

\author{
R. Katz and G. Huang \\ University of Nebraska-Lincoln, Lincoln NE 68588-0111, USA
}

\begin{abstract}
Data for the loss of reproductive integrity of Tradescantia stamen hairs irradiated with $250 \mathrm{keV} \mathrm{X}$ rays and 0.43 and $5.6 \mathrm{MeV}$ neutrons are fitted with radiosensitivity parameters from track theory, with $\mathrm{E}_{0}$ and $\mathrm{m}$ from $\mathrm{X}$-ray data while $\sigma_{0}$ and $\mathrm{k}$ are then found from neutron irradiations. The X-ray data display a clear shoulder with $100 \%$ survival below $0.18 \mathrm{~Gy}$ and a "linear tail." Data for abnormal metaphases and chromatid exchanges in Chinese Hamster cells have also been fitted with parameters. Parameters for abnormal metaphases are nearly identical with those obtained years ago for cell killing from data in the same paper, strongly supporting the view that cell killing arises from chromosome aberrations. These dose-response curves are also shouldered with a "linear tail."
\end{abstract}

\section{Introduction}

Parameters of the track theory of cellular survival [1] have been fitted to data for cell survival and cell transformation after exposure to a series of gammaray and heavy-ion irradiations with particles having a wide range of atomic numbers and energies. Once the parameters characteristic of a particular substance are obtained, it is possible to calculate the response to a mixed radiation environment whose secondary particle charge-energy spectrum is known, such as neutron irradiation or the spread Bragg peak of an irradiation with beams of heavy ions.

Here we extend these proceduresin two ways.

Wehave fitted parameters to data for cell survival in Tradescantia irradiated with $250 \mathrm{kVp}$ X rays and with neutrons of two different energies. Data obtained with neutrons are not well suited to modelling, for the effects are produced by a spectrum of secondary fragments. The "dynamic range" of such data is too limited to enable us to make a unique fit of parameters to the data. The results are of interest particularly because the gamma-ray data display a clear shoulder, with no measurable radiation damage below 0.15 Gy and a long linear tail, and thus are an exception to the prevailing view that radiobiological data are well fitted by the " $\alpha-\beta$ model."

We have fitted parameters to data for chromatid exchanges and to chromosome aberrations in Chnese hamster cells after a series of bombardments with gamma rays and ions of different atomic number and energy. This is our first successful attempt to deal with chromosome aberrations. We think it remarkable that the parameters we have obtained for chromosome aberrations are very close to parameters obtained years earlier for cell survival. The data for chromosome aberrations lie atop the survival curves calculated earlier from our cell survival parameters, without the fluctuation at low gamma-ray dose which is characteristic of the survival data. These results suggest that cell survival is linked to freedom from chromosome aberrations. The chromosome aberration data display a clear shoulder, which again cannot be fitted by the $\alpha-\beta$ model.

\section{Tradescantia}

Data for the survival of Tradescantia after $\mathrm{X}$ irradiation [2] enable us to estimate the parameters and $\mathrm{m}$ of our multitarget cell survival model. With these in hand, we attempt to find the parameters $\sigma_{0}$ and $\mathrm{K}$ from the survival data after neutron irradiation, making use of the spectrum of secondary charged particles after irradiation of tissue with $0.5 \mathrm{MeV}$ neutrons [3] to approximate the $0.43 \mathrm{MeV}$ neutrons used in the experiment, and the spectrum of neutrons from the Hammersmith Hospital neutron generator (mean energy $7.5 \mathrm{MeV}$; secondary particle spectrum from J. A. Dennis, 1972, private communication) to approximate the secondary particle spectrum from the Krakow generator yielding neutrons of mean energy 5.6 $\mathrm{MeV}$ used in this experiment.

Our parameters are not unique, for the data lack dynamic range. Our results for two sets of parameters, based on $\mathrm{m}=1.5$ or $\mathrm{m}=2$, are shown in Figure 1 . Of these we prefer the parameters based on $m=2$ for the agreement with the lowest dose X-ray data, but the decision is not clear. The neutron data are inadquate for a clear decision regarding the evaluation of the parameters. 


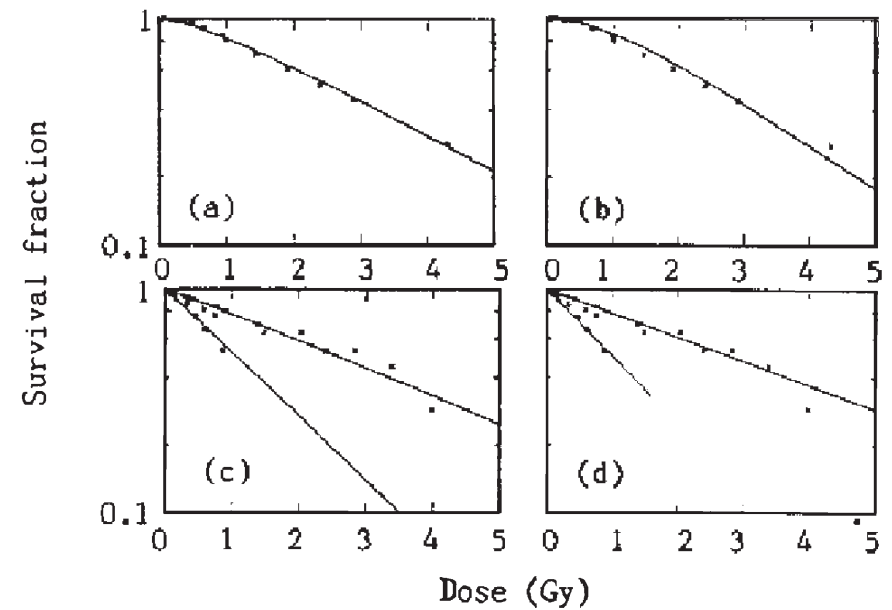

Figure 1. Parametric fits to cell survival in Tradescantia [2]. (a) $X$ ray: $\mathrm{m}=1.5, \mathrm{~K}=1900, \mathrm{E}_{0}=2.6 \mathrm{~Gy}, \mathrm{\sigma}_{0}=4.0 \times 10^{-7} \mathrm{~cm}^{2}$. (b) $\mathrm{X}$ ray: $\mathrm{m}=2, \mathrm{k}=1000, \mathrm{E}_{0}=2.1 \mathrm{~Gy}, \sigma_{0}=3.5 \times 10^{-7} \mathrm{~cm}^{2}$. (c) and $(\mathrm{d})$ $\mathrm{o}=0.43 \mathrm{MeV}$ neutrons; $x=5.6 \mathrm{MeV}$ neutrons.

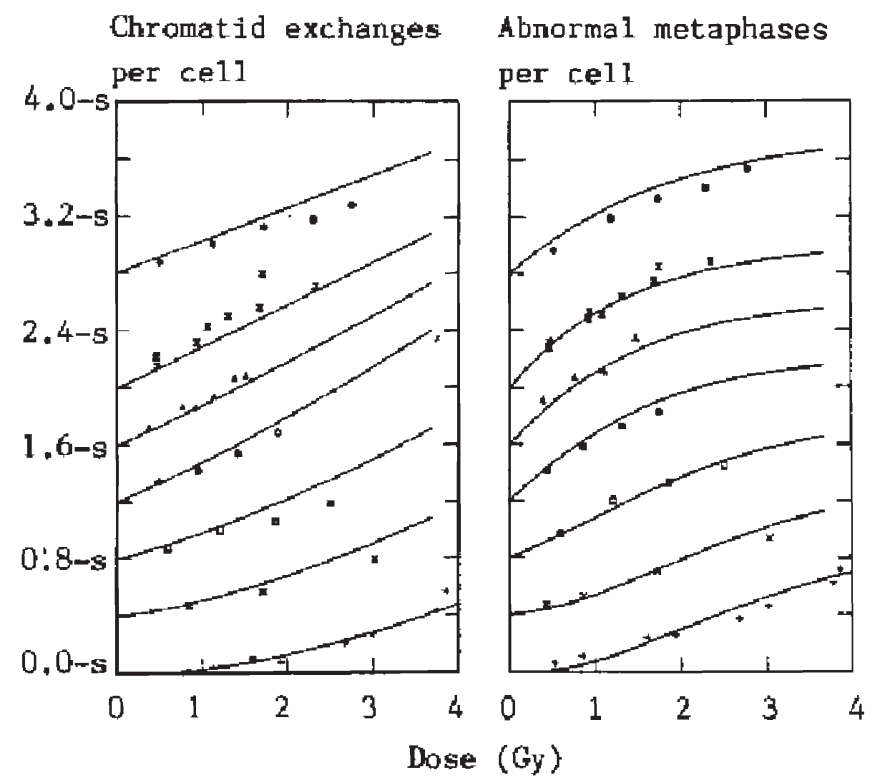

Figure 2. Parametric fits to chromatid exchanges and abnormal rnetaphases in Chinese hamster cells [4].

$$
\begin{aligned}
& \text { Chromatid exchanges: Abnormal metaphases: } \\
& \mathrm{m}=2, \mathrm{k}=1400 \quad \mathrm{~m}=3, \mathrm{k}=900 \\
& \mathrm{E}_{0}=25 \mathrm{~Gy} \\
& \sigma_{0}=6.5 \times 10^{-9} \mathrm{~cm}^{2} \\
& \text { Symbols: } \\
& \mathrm{E}_{0}=1.82 \mathrm{~Gy} \\
& \sigma_{0}=3 \times 10^{-7} \mathrm{~cm}^{2} \\
& +0.0 \times \text { ray } \\
& \times \quad 0.4 \mathrm{He}, 40 \mathrm{MeV} \\
& \text { } 0.8 \mathrm{Li}, 58 \mathrm{MeV} \\
& \text { ○ } 1.2 \mathrm{Li}, 30 \mathrm{MeV} \\
& \Delta 1.6 \mathrm{~B}, 102 \mathrm{MeV} \\
& \text { X } 2.0 \mathrm{C}, 106 \mathrm{MeV} \\
& \text { ( } 2.8 \mathrm{O}, 131 \mathrm{MeV}
\end{aligned}
$$

\section{Chinese Hamster Cells}

Studies of the effects of high LET irradiation on Chinese hamster cells [4] resulted in information for cellular survival, chromatid exchanges, and abnormal metaphases. The aberration data were scored as the number of chromatid exchanges per 100 cells and as the number of abnormal metaphases per 100 cells. In regard to the chromatid exchanges, we divided the number of exchanges by 22 (the number of chromosomes per cell) to find the probability of a "hit" leading to a chromatid exchange. These data were fitted by the equations of the cell survival theory. Our calculations for the probability of a chromatid exchange were then multiplied by 22 to yield the number of exchanges per cell. The data for abnormal metaphases were inverted to obtain the fraction of cells without abnormal metaphases. This was treated in a manner similar to cellular survival. Our results are compared with the experimental data in Figure 2.

\section{Cellular Survival and Normal Metaphases}

Parameters for abnormal metaphases were remarkably similar to those for cellular survival obtained years ago [5]. In consequence, we prepared Figure 3 to display on a single-figure the results for the fraction of cells free from abnormal metaphases and the fraction of surviving cells, as a function of the absorbed dose from the range of bombardments used in these experiments. Aside from the experimental data for normal metaphases after irradiation with oxygen ions at $131 \mathrm{MeV}$, the data points for normal metaphases and for cell survival could be fitted by the same parameters. Even more strongly than the original authors observation of a similarity in RBEs for the two end points, this plot supports the view that chromosome aberrations are responsible for cell killing.

\section{Acknowledgements}

This work is supported by the United States Department of Energy. 


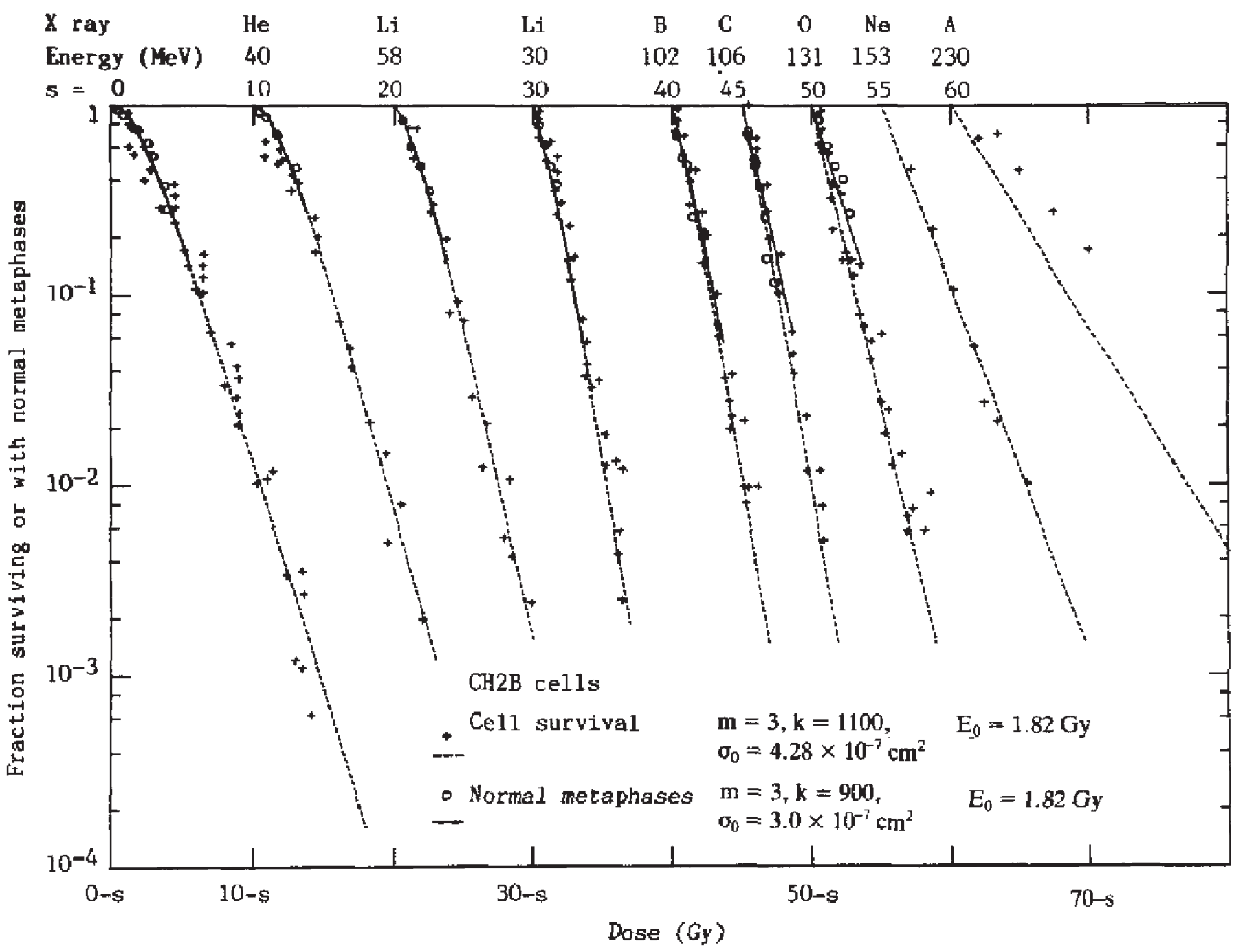

Figure 3. Fraction of surviving cells and fraction of cells with normal metaphases [4].

\section{References}

1. Katz, R., and Sharma, S. C. Response of Cells to Fast Neutrons, Stopped Pions, and Heavy Ion Beams. Nucl. Instrum. Methods. 110, 93-116 (1973).

2. Underbrink, A. G., Huczkowski, J., Woch, E., Gedlek, E., Cebulska-Wasilewska, A., Litwiniszyn, M., and Kasper, E. The Relationship of Different Somatic Mutations Induced by Neutrons and X Rays to Loss of Reproductive Integrity in Tradescantia Stamen Hairs. Report 1039/B (Institute of Nuclear Physics, Krakow) (1978).

3. Caswell, R. S., and Coyne, J. J. Interaction of Neutrons and Secondary Charged Particles with Tissues: Secondary Particle Spectra. Radiat. Res. 52, 448 (1972).
4. Skarsgard, L. D., Kihlman, B. A., Parker, L., Pujara, A. M., and Richardson, S. Survival, Chromosome Abnormalities, and Recovery in Heavy-Ion amd X-irradiated Mammalian Cells. Radiat. Res. Suppl. 7, 208-221 (1967).

5. Roth, R.A., Sharma, S. C., and Katz, R. Systematic Evaluation of Cellular Radiosevsitivity Parameters. Phys. Med Biol. 21, 491-503 (1976). 